\title{
Home Equity Bias
}

\author{
Ume Salma Akbar* \\ Department of Business Administration, Sukkur IBA, Sukkur 65200, Pakistan \\ Mubasher Ali Jamro \\ Department of Business Administration, Sukkur IBA, Sukkur 65200, Pakistan
}

Zulfiquar Ali Shah

Department of Management Sciences International Islamic University, Islamabad, Pakistan

\begin{abstract}
:
This study is aimed to investigate the factors that are intended to lessen the home equity bias or became a base for foreign diversification. By using the foreign diversification of twenty-one developing countries over a period of ten years and incorporating the effect of nine important variables for exploring their effect on home bias. The results from Random effect panel regression shows a diminishing trend of investors towards home equity biasness and the contributing factors for lessening this bias are local market share in world market capitalization and information available to investors and trade opening.
\end{abstract}

Keywords: Behavioral Finance, Foreign Diversification, Behavioral Finance, Political risk

Page: 40 - 56

*Email: u.salma@iba-suk.edu.pk

$P$ - ISSN: 2313-1217 @ 2014 Sukkur Institute of Business Administration - All rights reserved 


\section{Introduction}

According to standard Finance, all the rational investors want to diversify the unsystematic risk a part of their investment, by portfolio formation. Hence investors successfully can get rid of diversifiable risk but there have always been some assumption taken in standard finance models, which should never be relaxed in order to get results according to standard finance theories. As the modern portfolio theory which states that rational investor will always make a portfolio that will lay on efficient frontier but this is again assumptions based. Implementation for standard finance can never bring the required results until and unless the pre described assumptions do not hold. So violation of one assumption can lead to unexpected results. These proposed discrepancies are the result of human element the (actual decision makers') omission in standard finance.

Standard finance can disseminate information but the human cognitive abilities will process and covert this information according to their frame of references that will strongly affect investor's financial choices.

Despite the greater advantages of international diversification, investors prefer to invest in local equity, in international finance this term is referred as "Home Equity Bias".

This behavioral stand point is supported by various previous studies as Coval and Moskowitz (1999) found international markets investors strongly prefer domestic equities even over the gains of international diversification by virtually ignoring foreign opportunities

This study is supposed to serve three objectives, first Home bias is the results of certain costs taxes, transactions cost, inflation risk, exchange rate risk, government rules \& regulations, limited information, time difference. Second or this is biased behavior of investor towards their home country equity. Third to incorporate political instability and its linkage with home bias in a country like Pakistan that is highly exposed to political insatiability shocks since its establishment.

Theoretical base suggests that it is a tendency for investors to invest in a large amount of domestic equities, despite the purported benefits of diversifying into foreign equities. This bias is believed to have arisen as a result of the extra difficulties associated with investing in foreign equities, such as legal restrictions and additional transaction costs.

Moreover here are certain problems associated with home bias puzzle like inefficient portfolio allocation .This phenomenon is completely against diversification theory, in the light of previous researches home bias is also explained with support of certain investment barriers including foreign taxes, high transaction cost foreign and local government restrictions. But investor strong inclination and preference towards home equity remains constant after a remarkable diminish in restrictions.

The study that is quite important in Pakistani perspective as this is a developing country where the stock exchanges are of not level of developed countries and where there high political risk in terms of instability is available. so investor can become well off by making a portfolio that is made by foreign diversification. 
The rest of this paper proceeds as follows. Section 2 briefly explains previous work done on this topic in the shape of literature review. Section 3 motivates the research methodology and explains the measurement of foreign diversification. Section 4 provides results of various statistical tests. Section 5 concludes.

\section{Literature Review}

Financial theory advocates greater benefits of international equity diversification. Many authors including Solnik (1974), French and Poterba (1991), Tesar and Werner (1995), Lewis (2007) and Coeurdacier and Gourinchas (2013) have emphasis low risk and high returns of international diversification. Theoretical model put forwarded by Michaelides (2005) also suggest that investors may be better off to diversify its investment in foreign equity to avoid income shocks leading to low domestic returns.

Despite the greater advantages of international diversification, investors prefer to invest in local equity, in international finance this term is referred as "Home Equity Bias".

Many authors have worked upon various empirical explanations for Home Equity Bias and tried to solve this puzzle by taking different market frictions such as taxes, transactions cost, inflation risk, exchange rate risk, government rules $\&$ regulations, limited information and time difference.

The studies of Black (1974), Stulz (1981), and Lewis (2007) tried to explain the Home Equity Bias in the light of tax discrepancies by suggesting that investors may have to bear additional transactional cost of holding foreign equity due to taxes. Further Cooper and Kaplanis (1994) added that the investors prefer local equity as it provides hedge against inflation. Kang \& Stulz (1995) and Stulz \& Wasserfallen (1995) highlighted the institutional policies, rule and regulation could be the reason for local investment preference. But, these arguments were negated by Tesar and Werner (1995) work, who found that the foreign equity has higher turnover rate compared to local equity.

Moreover French and Poterba (1990) studied the pattern of holding Japanese and U.S. stocks and come up with a conclusion that there was very little international diversification in Both Japanese and U.S investors portfolios and this was the result of Home bias phenomenon as here benefits of going global in terms of higher returns were quite greater than its costs .

French and Poterba (1991) further extended their work and presented model which shows that the investors perceive higher expected returns in local market than in foreign market. It is investor's choice which play influential role in investment decision in Local equity rather than institutional factors. With regard to preference of local equity investment over foreigner one Frankel (1993) suggested that the local investor perceive investment in their local currency less risky than foreign currency.

The Home Bias Puzzle was moreover explored by Bellah and Sendi (2010) Lane and Milesi-ferretti (2003) and Karlsson and Nordén (2007) who tried to explain the home equity bias on the basis of international asset pricing models by taking into account the factors such as exchange rate risk, inflation risk, taxes, transactions costs, human capital, market restrictions and asymmetric 
information. They conclude these factors don't contribute a lot in investment diversification decision. The study argued that the investors are subject to behavioral biases when making diversification decision.

Standard Finance model suggest that home equity bias could be explained through information asymmetries. The studies of Bernnan and Cao (1997) Boyle, Uppal and Wang (2003) and Jeske (2001) incorporated Information asymmetries as probable cause for home equity bias and suggested that if investors are ambiguous about the returns on international portfolio they will not diversify and invest in local stocks hence informational dissimilarities between local and foreign investors will path away for Home equity bias.

Ahearne and Warnock (2004) also recommended information costs as an indirect barrier to international investment that owe to the poor quality and low credibility of financial information in many countries. Nieuwerburgh and Veldkamp (2007) criticize information-based models of the home bias and argue that if local investors have limited information about foreign market then they should acquire information and reduce uncertainty. Coval (2000) and Evans and Lyons (2004) oppose it by their studies where they found that despite greater availability of information investor still prefer to invest in local equity.

Hau (2000) examined the role of informational asymmetries across and location of investor in home equity bias and found that both factors do play a role in home equity bias.

Benigno and Nisticò (2009) were the authors who suggested that home equity bias is based on exchange rate risk and ambiguity aversion. In addition Bentabet and Fetni (2013) presented the currency index capital asset pricing model in presence of shadow costs of incomplete information

Kang and Stulz (1997) tried to explain home bias with respect to size of firms and they found foreign investors are strongly biased against small firms and due to this prefer to invest in large firms. Coval and Moskowitz (1999) contributed that U.S. investment managers' exhibit a strong preference for locally headquartered firms, particularly small, highly levered firms that produce nontrade goods.

Christelis, Jappeli, Padula (2007) studied about the relationship between cognitive abilities on holding of local stocks. They conclude that it is information constraints which prevent investors from diversification rather features of preferences or psychological traits

On the other hand some studies suggest that home equity bias is reducing as Amadi (2004), Coeurdacier and Rey (2011) suggested that due to factors like free trade, globalization, easily availability of information through internet and mutual funds markets have significantly reduced the home equity bias.

Recent studies indicate that information and transaction costs can be reduced through enhanced financial integration, which in turn significantly reduce equity home bias. Baele et al. (2007) and Sorensen et al. (2007) suggested that investors can trade assets and equities freely at lower cost as capital markets are increasing becoming more globally integrated, Furthermore, developing economic and financial integration would reduce information asymmetry between local and foreign 
investors, resulting in reduction of equity home bias. Baele et al. (2007) tested this hypothesis and identified that there is considerable decline in equity home bias of countries that are more financially integrated and linked with each other. Mondria and $\mathrm{Wu}$ (2010) developed a theoretical model and argued that with inadequate information and decreases in financial openness there is increase in home bias. They showed that at initially stage of financial liberalization local investors have more information about local market compared to foreign market and they prefer to invest local market resulting in increase in home bias. However, as local investors receive more information about foreign assets in advance stage of financial liberalization, local investors invest more internationally so home bias declines. Bekaert and Wang (2009) showed that familiarity and information factors, along with degree of capital market openness are crucial in explaining home bias as well as foreign bias. We have selected financial integration factor in our study due to fact that most of the literature dealing with financial integration impact on home bias has been largely limited to advanced and developed economies of Europe and United States.

Literature also suggests that the better regulatory quality significantly reduces equity home bias. Baele et al. (2007), Bekaert and Wang (2009), and Jochem and Volz (2011) have found that those countries which has strong rule of law, better protection for shareholder, and minimal corruption tends to reflect lower equity home bias.

Notable progress on home bias issue that also serve our this study area of research in a developing country like Pakistan was made by Alam, Arshad and Dr.Shah (2012) who studied the data of foreign diversification of nine developed nations and found that home equity bias has reduced due to trade openness and easily available data.

Area of research for this paper would be to analyze the role is to search out positive link between political instability and foreign diversification by incorporating different measures of accessing political instability country.

\section{Data and Methodology}

This is secondary data based study which is aimed to investigate how much investors are biased towards home equity and investigate the influence of various factors on foreign diversification. For this regard 21 emerging countries Argentina, Brazil Bulgaria, Chile, China, Colombia, Estonia, Hungary, India, Indonesia, Malaysia, Mexico, Pakistan, Philippines, Poland, Romania, Russia, South Africa, Thailand, Turkey and Ukraine data consist of ten years' time span and ranges from 20032012 is taken. Sample was derived on the basis of the International Monetary Fund (IMF) categorization of countries labeled as "emerging economies". Proposed factors of the study are country market share of world capitalization, the difference between local market indexes return and world market index return, portion of export and import in gross domestic product (GDP), information available to investors, emerging markets share in world capitalization, country political insatiability (risk), regulatory quality of country, financial integration of local and global market and variation in exchange rate of country. 
Foreign Diversification is the dependent variable of the study that is calculated by using following equation:

$$
\begin{aligned}
& \text { Equation } 1 \\
& \text { Foreign diversification of a country, } \mathrm{FD}=\frac{\mathrm{FEA}_{\mathrm{x}, \mathrm{t}}}{\mathrm{SMCAP}_{\mathrm{x}, \mathrm{t}}+\mathrm{FEA}_{\mathrm{x}, \mathrm{t}}-\mathrm{FEL}_{\mathrm{x}, \mathrm{t}}}
\end{aligned}
$$

Where;

SMCAP $_{\mathrm{xt}}=$ Stock market capitalization of a country $\mathrm{x}$ at time $\mathrm{t}$

FEA $_{\mathrm{xt}}=$ Foreign equity assets held by a country $\mathrm{x}$ at time $\mathrm{t}$

FEL $_{\mathrm{xt}}=$ Foreign equity liabilities held by a country $\mathrm{x}$ at time $\mathrm{t}$

Equation (1) provides the details about each country foreign diversification. Higher value of the foreign diversification reflects that the inventors of particular country are investing in other country equities. Whereas, lower values of foreign diversification reflect the home equity bias attitude of investors of particular country.

Empirical specification: After calculating the foreign diversification position of each country, we conducted panel data analysis to identify what factors are crucial for explaining the home equity bias. We used equation (2) to run the panel data regression.

Equation 2

$$
\begin{gathered}
F D_{x, t}=\alpha+\beta_{1} M W C A P_{x, t}+\beta_{2} R D W L I_{x, t}+\beta_{3} S I E G D P_{x, t}+\beta_{4} I N F O_{x, t}+ \\
\beta_{6} P I_{x, t}+\beta_{7} R Q_{x, t}+\beta_{8} F I_{x, t}+\beta_{9} E R V_{x, t}+\varepsilon_{x, t}
\end{gathered}
$$

Where,

MWCAP $_{\mathrm{xt}}$ represents the market share of world capitalization of country, according to capital asset pricing model investors are required to diversify their portfolio with respect to country's world market capitalization share. Hence this factor should have significant relationship with foreign diversification.

$\mathrm{RDWLI}_{\mathrm{x}, \mathrm{t}}$ represents difference between the world market index and returns (annual) of local market index. The investors' foreign diversification is based on performance of foreign market so as foreign market performance increases likewise the foreign diversification. This is the variable that helps out for checking mindset of investor that either change in market returns also brings change in trend of foreign investment or leave it as it is.

Equation 3

$$
\text { RDWLI }_{\mathrm{xt}}=\text { Local Market Returns }- \text { World Market Returns }
$$

SIEGDP $_{x, t}$ represents the share of imports and exports share in Gross Domestic Product (GDP). This variable is used to measure the willingness of investor for foreign portfolio investment so it possesses a significant effect on foreign diversification. 


\section{Equation 4 \\ SIEGDP $_{\mathrm{xt}}=0.5[$ Import + Export $] /$ GDP}

INFO $_{x, t}$ is abbreviated for Information. It is regarded as quite influential factor that hinder or accelerate foreign diversification. Information availability is measured with the help of proxy of number of internet users at a country $\mathrm{x}$ at time $\mathrm{t}$.

$\mathrm{SEMCAP}_{\mathrm{t}}$, represents share of emerging markets in the world capitalization, this is time variant variable used to identify the role of emerging markets in foreign diversification.

$\mathrm{PI}_{\mathrm{x}, \mathrm{t}}$ represents Political Instability (Risk) of any country ${ }_{\mathrm{x}}$ at time ${ }_{\mathrm{t}}$ is taken as independent variable as the political environment of country can influence the investment decision of the investors.

$\mathrm{RQ}_{\mathrm{x}, \mathrm{t}}$ indicates regulatory quality index captures perceptions about government ability to formulate and implement comprehensive policies and regulations that promote development of private sector. It includes regulatory perception measures on transparency in financial institutions, access to capital markets, bank regulation, and legal framework.

$\mathrm{FI}_{\mathrm{x}, \mathrm{t}}$ represents Financial Integration. This independent variable measures the regional and global financial integration. Higher level of financial integration reduces transaction and information cost which in turn reduces the home equity bias. Financial Integration is measured through the Chinn-Ito index (KAOPEN 2006)

ERV $_{\mathrm{x}, \mathrm{t}}$ represents Exchange Rate Variation. It measures the fluctuations in nominal exchange rate of any country. Exchange rate volatility may increase the trading cost and reduce return therefore it is very important to understand the impact of exchange rate fluctuations on foreign diversification.

Data of Foreign equity holdings is taken from (IMF) international monetary fund's data mine. Data of Gross Domestic product (GDP), imports, exports and country wise market capitalization and nominal exchange rate is taken from the database of World Bank World development Indicator (WDI). World market capitalization data is collected from website indexmundi.com. Local and world market returns data is collected from Morgan Stanley Capital International (MSCI) indexes.

Internet user data was collected from international telecommunications Union year book statistics. Political risk and Regulation Quality data was collected from the World Governance Indicators Guide of International Country Risk (PRS). Financial Integration Data is collected from Dr. Hiro (Hiroyuki) Ito personal website.

\section{Results}

Foreign Diversification Results

We have measured the foreign diversification of each country with the help of equation (1). The calculation of foreign diversification of 21 countries for the period 2003 to 2012 is shown in Table 1. 
Ume Salma et al. / Home Equity Bias

Table 1 Foreign Diversification

\begin{tabular}{|l|l|l|l|l|l|l|l|l|l|l|l|}
\hline & Country & 2003 & 2004 & 2005 & 2006 & 2007 & 2008 & 2009 & 2010 & 2011 & 2012 \\
\hline 1 & Argentina & 16.9 & 16.0 & 13.9 & 13.2 & 15.4 & 13.7 & 19.2 & 14.6 & 20.8 & 26.3 \\
\hline 2 & Brazil & 1.4 & 0.9 & 0.7 & 0.7 & 0.6 & 1.0 & 1.0 & 1.2 & 1.8 & 1.4 \\
\hline 3 & Bulgaria & 0.1 & 0.6 & 0.5 & 1.7 & 2.0 & 2.2 & 7.1 & 10.4 & 6.1 & 9.1 \\
\hline 4 & Chile & 11.5 & 12.2 & 15.0 & 21.0 & 24.2 & 21.3 & 26.7 & 22.6 & 23.4 & 24.5 \\
\hline 5 & China & 20.8 & 27.4 & 25.9 & 13.3 & 8.0 & 9.5 & 9.5 & 11.5 & 13.3 & 15.2 \\
\hline 6 & Colombia & 5.3 & 2.3 & 2.2 & 2.8 & 2.3 & 1.9 & 3.4 & 2.9 & 3.7 & 2.9 \\
\hline 7 & Estonia & 6.0 & 10.2 & 28.9 & 28.8 & 42.7 & 45.2 & 42.7 & 59.2 & 70.7 & 63.3 \\
\hline 8 & Hungary & 3.3 & 6.3 & 9.4 & 18.2 & 22.0 & 34.3 & 36.7 & 39.7 & 36.8 & 33.8 \\
\hline 9 & India & 0.0 & 0.0 & 0.0 & 0.0 & 0.1 & 0.2 & 0.1 & 0.1 & 0.1 & 0.1 \\
\hline 10 & Indonesia & 0.0 & 0.1 & 0.1 & 0.3 & 0.5 & 0.6 & 0.6 & 0.3 & 0.4 & 0.5 \\
\hline 11 & Malaysia & 0.6 & 0.6 & 1.0 & 1.8 & 3.4 & 6.7 & 8.4 & 6.6 & 7.2 & 7.4 \\
\hline 12 & Mexico & 0.5 & 2.2 & 1.9 & 2.2 & 1.3 & 1.1 & 0.7 & 0.5 & 0.7 & 0.3 \\
\hline 13 & Pakistan & 0.4 & 0.4 & 0.8 & 0.5 & 0.5 & 0.5 & 0.3 & 0.3 & 0.4 & 0.4 \\
\hline 14 & Philippines & 0.8 & 0.7 & 0.3 & 0.2 & 0.2 & 0.1 & 0.0 & 0.0 & 0.0 & 0.0 \\
\hline 15 & Poland & 0.7 & 1.2 & 2.1 & 4.0 & 6.3 & 5.4 & 6.0 & 6.1 & 5.9 & 6.0 \\
\hline 16 & Romania & 0.2 & 0.3 & 0.9 & 1.9 & 2.2 & 4.0 & 2.0 & 2.5 & 4.9 & 8.1 \\
\hline 17 & Russia & 0.0 & 0.1 & 0.1 & 0.1 & 0.3 & 0.8 & 0.3 & 0.5 & 0.8 & 0.7 \\
\hline 18 & South Africa & 13.8 & 9.6 & 10.8 & 9.3 & 8.6 & 11.8 & 12.8 & 19.4 & 22.7 & 23.0 \\
\hline 19 & Thailand & 0.4 & 0.7 & 1.0 & 1.6 & 2.2 & 2.7 & 3.3 & 2.1 & 2.7 & 2.3 \\
\hline 20 & Turkey & 0.1 & 0.1 & 0.1 & 0.1 & 0.0 & 0.1 & 0.1 & 0.1 & 0.2 & 0.1 \\
\hline 21 & Ukraine & 0.3 & 0.2 & 0.2 & 0.1 & 0.1 & 0.1 & 0.3 & 0.1 & 0.1 & 0.1 \\
\hline
\end{tabular}


Table 1 indicated that almost all countries show increasing trend in foreign diversification. For the ease of analysis results of from 2003 to 2012 were averaged and plotted in Graph 1

Graph 1

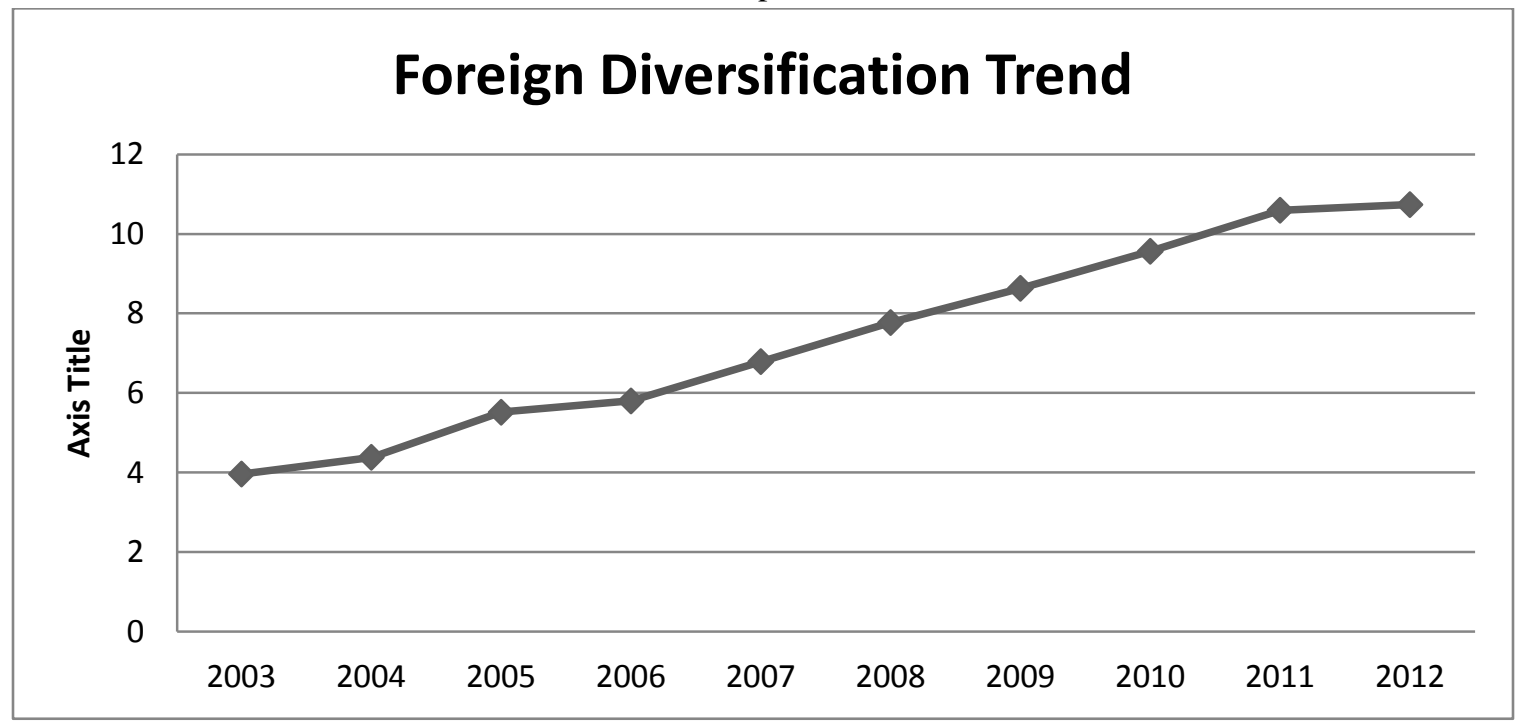

Graph 1 shows the increasing trend in foreign diversifications of countries. However, this increase is still not significant enough to conclude that the home equity bias is eliminated. Country wise average results are plotted in Graph 2.

Graph 2

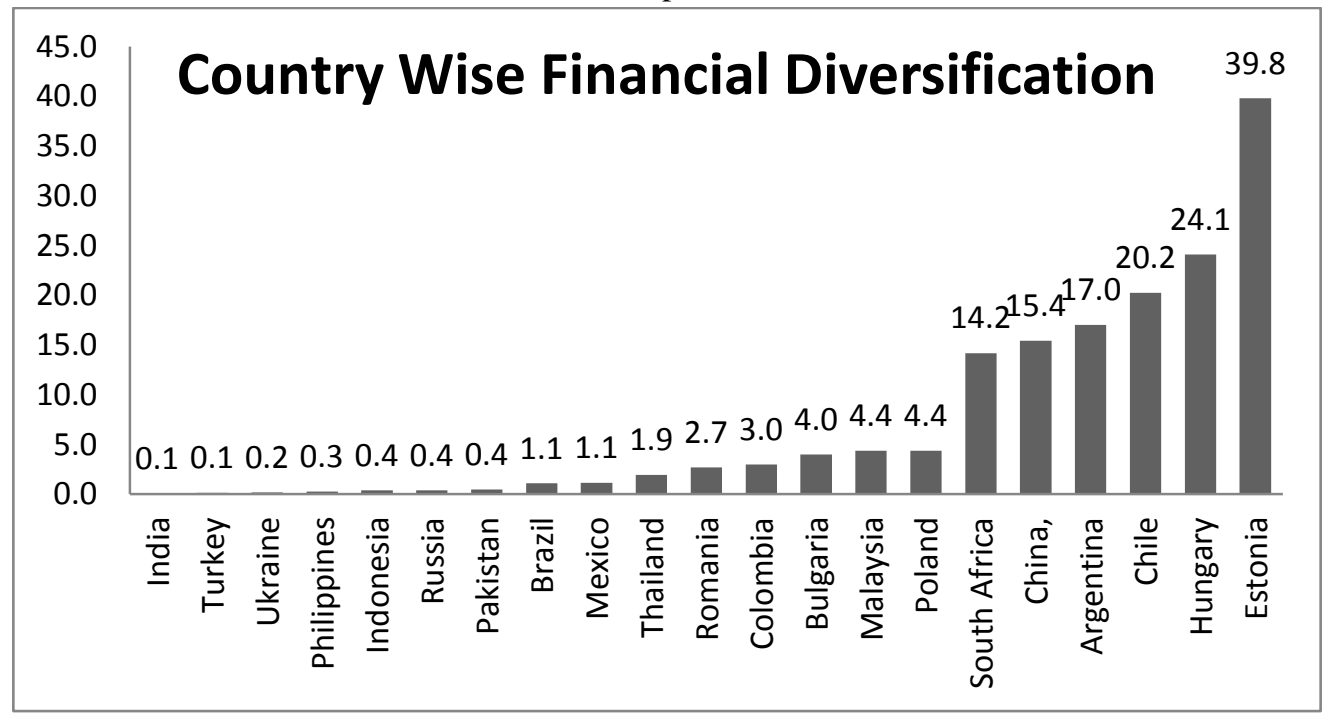

Results in graph 2 depicts that Estonia has highest foreign diversification percentage of $39.8 \%$ where as India has lowest percentage of $0.1 \%$. Graph 2 further indicates only six countries South Africa, China, Argentina, Chile, Hungry and Estonia has more 10\% portfolios internationally diversified. 
While the other fifteen countries show below than 5\% international diversification, it means that most of the countries invest locally and they are biased towards foreign equity.

Summary Statistics is given in table 2:

Table 2 Summary Statistic

\begin{tabular}{|l|l|l|l|l|l|}
\hline Varaibles & Observations & Mean & Maximum & Minimum & Std. Dev. \\
\hline FD & 210 & 0.073762 & 0.707000 & 0.000000 & 0.119287 \\
\hline MWCAP & 210 & 0.791567 & 10.56900 & 0.003000 & 1.528789 \\
\hline RDWLI & 210 & -354.3992 & 5780.030 & -1503.889 & 1161.491 \\
\hline SIEGDP & 210 & 40.10585 & 105.1869 & 11.05915 & 22.84205 \\
\hline INFO & 210 & 28.30242 & 79.00000 & 1.686000 & 19.68365 \\
\hline SEMCAP & 210 & 17.87881 & 21.25707 & 13.82118 & 2.557135 \\
\hline PI & 210 & 0.692523 & 0.901515 & 0.405303 & 0.090295 \\
\hline RQ & 210 & 0.709333 & 1.000000 & 0.270000 & 0.152015 \\
\hline FI & 210 & 0.188269 & 2.439009 & -1.863972 & 1.328095 \\
\hline ERV & 210 & -0.33071 & 47.91900 & -28.233 & 8.856412 \\
\hline
\end{tabular}

Summary statistics reflects raw data results. Variables are defined as under:

FD

MWCAP

RDWLI

SIEGDP

INFO

SEMCAP

Capitalization

PI

RQ

FI

ERV
Foreign Diversification

Market to World Capitalization

Local minus World returns

Share of Export \& Import in GDP

Information

Share of Emerging markets in World Market

Political Instability

Regulation Quality

Financial Integration

Exchange rate Variation

Table 2 shows the mean, minimum and maximum values and standard deviation of each variable. Mean value of Foreign Diversification is 0.073 which suggest overall low foreign diversification. Similarly negative mean values of Local to World market returns and Exchange rate volatility reflect 
that local market return are lower than world market and there is high exchange rate volatility in countries.

\subsection{Panel Data Results}

We used panel data regression on 21 countries balanced data from 2003 to 2012 to identify which factors have important role in explaining foreign diversification.

We conducted Hausman test on balanced panel data to check whether to use fixed effect or Random effect model. Hausman test showed that cross-section results are insignificant and probability value is above level of 0.05. On basis of Hausman test results, we used random cross-section and random period. Results of Panel data analysis with random effect are given in table 3.

Table 3 Panel Data Analysis

\begin{tabular}{|l|l|l|l|}
\hline \multicolumn{4}{|l|}{ RANDOM EFFECT PANEL REGRESSION RESULTS } \\
\hline Variables & Coefficient & t-Statistic & Prob. \\
\hline CONSTANT & -0.068365 & -0.730950 & 0.4657 \\
\hline MWCAP & -0.024863 & -5.118130 & 0.0000 \\
\hline RDWLI & -0.000135 & -1.770596 & 0.0782 \\
\hline SIEGDP & 0.001853 & 2.824955 & 0.0052 \\
\hline INFO & 0.002032 & 4.110402 & 0.0001 \\
\hline SEMCAP & 0.004105 & 1.791808 & 0.0747 \\
\hline PI & -0.008371 & -0.103847 & 0.9174 \\
\hline RQ & -0.058024 & -1.115428 & 0.2660 \\
\hline FI & -0.005747 & -0.804351 & 0.4221 \\
\hline ERV & 0.000372 & 0.831864 & 0.4065 \\
\hline & R2 $=0.358$ & & \\
\hline
\end{tabular}

Variables are defined as under:

FD

MWCAP

RDWLI

SIEGDP

INFO
Foreign Diversification

Market to World Capitalization

Local minus World returns

Share of Export \& Import in GDP

Information 
SEMCAP

Capitalization

PI

RQ

FI

ERV
Share of Emerging markets in World Market

Political Instability

Regulation Quality

Financial Integration

Exchange rate Variation

In table 3, results of panel regression with random effect model suggest that three variables, local market capitalization share of world market capitalization (MWCAP), share of Import and Export in GDP (SIEGDP) and information (INFO) play an important role in foreign diversification as well as in investor decision making.

Local market capitalization share in world market capitalization (MWCAP) results indicates interesting facts. Since coefficient of MWCAP variable is negative, which indicates negative relationship between MWCAP and foreign diversification. It means higher the local market share of world market capitalization lower the foreign diversification. One possible explanation of this negative relationship could be derived from the fact that since investors of those countries having bigger share in world capitalization do not perceive additional benefit to international diversify because their country market is strong and major player in world market and therefore they prefer to invest locally which in turn reflect as home equity bias attitude of investors.

Share of Import and Export in GDP (SIEGDP) and information (INFO) has positive coefficients which indicate positive relationship with foreign diversification. Higher the information available to investor more they will invest internationally. Similarly, more trade friendly policies country applies more investors will be willing to invest internationally.

Results about trade openness are consistent with previous studies that it boosts the foreign diversification. Hence study's hypothesized reasons for increment in foreign diversification is supported and justified. Accordingly as long as an economy is open it will pave the way for foreign diversified investment and became an attractive feature for foreign investment.

Information factor is not a supporting icon for foreign diversification is affected by, hence became insignificant over here, acceptability of investment is not only possible due to information availability. These findings are consistent with Brannan and Cao (1997) and Ahearne, Griever and Warnock (2004) studies.

Negative values of coefficient of country political risk, difference of local and world market return, regulation quality and Financial Integration indicate that investors sensitivity towards perceived country political situation, rules and regulation, financial structure and return of country's market but there no linkage have been observed between these variables and foreign diversification

\section{Conclusion}

The aim of this study was to explore the potential influential factors that affect and modify investors' attitude towards foreign investment than investing domestically. While taking in account 21 
developing counties for the period of 10 years we observed upward trend in foreign investment. But there still majority of sample countries have very low level of foreign diversification which indicated that investor still prefer to invest in their local equities which results home equity bias attitude.

To further analyze the potential influential factors behind the home bias attitude we applied panel data random effect model on nine variables, Market to World Capitalization, Local minus World returns, Share of Export \& Import in GDP, Information, Share of Emerging markets in World Market Capitalization, Political Instability, Regulation Quality, Financial Integration and Exchange rate Variation.

On the basis of accumulated results we came with a conclusion that local market share in world capitalization, Information available to investors and trade openness are significant factors which influences the foreign diversification. Even though variables like Political factor, Regulation Quality, financial Integration and difference between local and world return do not display significant relationship with the foreign diversification but their negative coefficient value reflect investor's sensitivity towards these factors. This study is consistent with the study of Alam, Arshad and Shah (2012) with a difference and their suggested future research area of analyzing political instability (risk) effect is insignificant as per study's results. Conclusively this study summarizes home bias is diminishing and investor prefer to invest internationally.

Future research may incorporate time variation in trading hours on foreign investment and home biasness and try to find out its linkage with home investment. 


\section{References}

Ahearne, A. G., Griever, W. L., \& Warnock, F. E. (2004). Information costs and home bias: an analysis of US holdings of foreign equities. Journal of International Economics, 62(2), 313-336.

Alam, A., Arshad, M. U., \& Shah, S. Z. A. (2012) Home Equity Bias: The Downward Trend. World Applied Science Journal, 18(9) 1279-1284.

Amadi, A. A. (2004). Equity Home Bias: A Disappearing Phenomenon? SSRN Electronic Journa. https://fdic.gov/bank/analytical/CFR/2005/feb/CFR_2005_Amir2.pdf

Baele, P., C. Pungulescu, and J. T. Horst. (2007). Model Uncertainty, Financial Market Integration, and the Home Bias Puzzle Journal of International Money and Finance 26: 606-630

Bekaert, G. and X. Wang. 2009. Home Bias Revisted. Mimeo

Baxter, M., \& Jermann, U. J. (1997). The international diversification puzzle is worse than you Think.The American Economics Review, Vol.87, No.1, 170-180

Baxter, M., Jermann, U. J., \& King, R. G. (1998). Nontraded goods , nontraded factors , and international non-diversification, Journal of International Economics 44, 211-229.

Bellalah, M., \& Sendi, I. (2010). The Equity Home Bias : Explanations and Financial Anomalies. International Journal of Economics and Finance, 78-96.

Benigno, P., \& Nisticò, S. (2009). INTERNATIONAL PORTFOLIO ALLOCATION UNDER MODEL UNCERTAINTY. NBER Working Paper Series www.nber.org/papers/w1473

Bentabet, A., \& Fetni, M. (2013). Information costs and its effects on international portfolio choice. Issues in Business Management and Economics, 1(June), 37-46.

Bernnan, M. J., \& Cao.H. H (1997). International Portfolio Investment Flows. The Journal of Finance Volume 52, Issue 5, pages 1851-1880

Black .F, (1974) International capital market equilibrium with investment barriers Journal of Financial Economics Volume 1, Issue 4, Pages 337-352

Bordo, M. D., Eichengreen, B., \& Irwin, D. A. (1999). Is Globalization Today Really Different Than Globalization a Hundred Years Ago?, National Bureau of Economic Research: Cambridge, MA, NBER Working Paper 7195 (Prepared for the Brookings Trade Policy Forum on. "Governing in a Global Economy," Washington, D.C

Boyle, P., Uppal, R., \& Wang, T. (2003). Ambiguity Aversion and the Puzzle of Own-Company Stock in Pension Plans, Institute of Finance and Accounting, London working paper ; 390 
Chinn, Menzie D. and Hiro Ito (2006).What Matters for Financial Development? Capital Controls, Institutions, and Interactions," Journal of Development Economics, Volume 81, Issue 1, Pages 163 192 (October)

Christelis, D., Jappeli, T., \& Padula, M. (2007). Cognitive Abilities and Portfolio Choice, European Economic Review Volume 54, Issue 1, January 2010, Pages 18-38.

Coeurdacier, N., \& Gourinchas, P. (2013). When Bonds Matter: Home Bias in Goods and Assets. NBER Working Paper No. 17560 http://www.nber.org/papers/w17560

Coeurdacier, N., \& Rey, H. (2011). Home Bias in Open Economy Financial Macroeconomics NBER Working Paper No. 17691 . http://www.nber.org/papers/w17691

Cooper, I., \& Kaplanis, E. (1994). Home Bias in Equity Portfolios , Inflation Hedging , and International Capital Market Equilibrium. The Review of Financial Studies, 7(1), 45-60.

Coval, J. D. (2000). International Capital Flows When Investors have Local Information, Harvard Business School Working Paper, No. 04-026

Coval, J. D., \& Moskowitz, T. J. (1999). Home Bias at Home : Local Equity Preference in Domestic Portfolios, The Journal Of Finance • Vol. Liv, No. 6, 2045-2073.

Evans, M. D. D., \& Lyons, R. K. (2004). A New Micro Model Of Exchange Rate Dynamics. NBER Working Paper No. 10379 http://www.nber.org/papers/w10379

Foad, H. S. (2012). Equity Home Bias and the Euro, Social Science Research Network working paper http://ssrn.com/abstract $=959270$

Frankel, J. A. (1993). The Internationalization of Equity Markets. National Bureau of Economic Research Working paper 4590

French, K. R., \& Poterba, J. M. (1990). Japanese and U.S cross-border common stock investments. Journal of the Japanese and International Economics 4, 476-493

French, K. R., \& Poterba, J. M. (1991). Investor diversification and international equity markets. National Bureau of Economic Research Working paper 3609

Griffin, J. M., \& Karolyi, G. A. (1998). Another look at the role of the industrial structure of markets for international diversification strategies, Journal of Financial Economics 50 351-373.

Halova, M. W. (2011). Multinational Production, Optimal Portfolios and Home Equity Bias, Journal of Boston College, 1-35.

Hatchondo, J. C. (2005). Asymmetric Information and the Lack of International Portfolio Diversification. International Economic Review, volume (49), number (4), (1297-1330) 
Hau, H. (2000). Location Matters : An Examination Of Trading Profits. Journal of Finance. Volume 56, Issue 5, pages 1959-1983

Jeske, K. (2001). Equity Home Bias: Can Information Cost Explain the Puzzle? Federal Reserve Bank of Atlanta ECONOMIC REVIEW Third Quarter 2001 (pp. 31-42).

Jochem, A. and U. Volz. 2011. Portfolio Holdings in the Euro Area-Home Bias and the Role of International, Domestic and Sector-Specific Factors. Deutsche Bundesbank Discussion Paper Series No. 07/2011. Frankfurt: Deutsche Bundesbank.

Kang, J.-K., Kim, Y.-C., Park, K.-J., \& Stulz, R. (1995). An Analysis of wealth effects of Japanese Offshore Dollar-Denominated Convertible and Warrant Bond Issues. Journak of Financial And Quantitative Analysis Vol. 30, No.2

Kang, J.-K., \& Stulz, R. M. (1997). Why Is There a Home Bias An Analysis of Foreign Portfolio Equity Ownership in Japan. Journal of Financial Economics 46 (1997) 3-28

Karlsson, A., \& Nordén, L. (2007). Home sweet home: Home bias and international diversification among individual investors. Journal of Banking \& Finance, 31(2), 317-333.

Lane, P. R., \& Milesi-ferretti, G. M. (2003). International Financial Integration, IMF Staff Papers Vol. 50, Special Issue

Lewis, K. K. (2007). Trying to Explain Home Bias in Equities and Consumption, Journal of Economic Literature Vol. 37(2), pp.571-608.

Michaelides, A. G. (2005). International Portfolio Choice, Liquidity Constraints and the Home Equity Bias Puzzle Journal of economic dynamics and control, 28 (3). pp. 555-594

Mondria, J. and T. Wu. 2010. The Puzzling Evolution of Home Bias, Information Processing, and Financial Openness. Journal of Economic Dynamics and Control. 34: 875-896.

Nieuwerburgh, S. Van, \& Veldkamp, L. (2007). Information Immobility And The Home Bias Puzzle. NBER Working Paper 13366 http://www.nber.org/papers/w13366

Obstfeld, M., \& Rogoff, K. (2001). The Six Major Puzzles in International Macroeconomics: Is There a Common Cause? NBER Macroeconomics Annual 2000, Volume 15, pp. 339-412.

Solnik, B. H. (1974) An equilibrium model of the international capital market, Journal of economic theory, vol (8), no.(4), pp: (500-524)

Sørensen, B., Y.T. Wu, O. Yosha, and Y. Zhu. 2007. Home Bias and International Risk Sharing: Twin Puzzles Separated at Birth. Journal of International Money and Finance. 26: 587-605

Stulz, R.M. (1981). On the effects of barriers to international investment. Journal of Finance VOL XXXVI No.4. 
Stulz, R., \& Wasserfallen, W. (1995). Foreign Equity Investment Restrictions and Shareholder Wealth Maximization Theory and Evidence. The Review of Financial Studies.Vol.8 No.4 pp: (10191057)

Tesar, L. L., \& Werner, I. M. (1995) Home bias and high turnover, Journal of International Money and Finance, 14(4), 467-492 